\title{
THE HSR AS AN INNOVATIVE AND ECOLOGICAL MODE OF TRANSPORT
}

\author{
Antoaneta Kirova \\ “Todor Kableshkov" University of Transport, Sofia, Bulgaria
}

CMESTE

JEL Category: L92, 018, R41

\begin{abstract}
High-speed rails (HSR) connects major cities in developed countries, as listed in the table below. Internationally HSR is developed only in Europe, aiming at the use of trans-European transport network (TEN-T) to link all high-speed lines on the continent into a proper integrated European high-speed network. In terms of the economic development, it is considered that HSR redirects development from one area to another and as far as safety is concerned, most potential rail passengers accept aviation as a safer mode of transport. Another positive outcome is the provision of a better choice of travel mode for public transport users, who already have a lot of options represented by a low-cost bus, a fast plane or a personalized car trip. The general review proves, that besides discussing pros and cons, among which the huge investments, the lack of certainty in the future use of HSR there are positive signs of development. The new trends envisage HSR for freight as well passenger traffic. Still, there is a danger that newer technologies in transportation will boost forward in the time necessary to build a high-speed route. The question who will use the high-speed lines, when air travel provides the high speed, the selfdriven cars allow for independent travels and public carriers provide Internet access and comfort to work on board remains.
\end{abstract}

Keywords: HSR, economic considerations, innovative mode of transport, political issues

\section{GENERAL REVIEW OF HSR DEVELOPMENT}

High-speed rails (HSR) are an integrated railway system of specialized rolling stock and dedicated tracks which differ from the so-called "conventional" railways. Multiple definitions for high-speed rail are in use worldwide. The European Union Directive 96/48/EC (European Commission, 2004) defines high-speed rail in terms of:

The address of the author: Antoaneta Kirova

䒠·toni.kirova@gmail.com
1. Infrastructure meaning specially constructed or upgraded track for high-speed travel;

2. Minimum speed of $250 \mathrm{~km} / \mathrm{h}$ on specially built lines and approximately $200 \mathrm{~km} / \mathrm{h}$ on existing upgraded lines;

3. The operating conditions require rolling stock specially designed for compatibility with infrastructure, providing the quality of service and safety levels (UIC, 2016).

High-speed rails connect major cities in developed countries, as listed in the table below. Internationally HSR is developed only in Europe, aiming at the use of trans-European transport network (TEN-T) to link all high-speed lines on the continent into a proper integrated European high- 
speed network. The liberalization of the mainline international passenger railway market on 1 January 2010 will also allow operators to compete and offer users a wider range of transport options.

According to Ginés de Rus, I. Barron, J. Campos, etc. (Baron, et al., 2009, p. 24), three different factors contribute to the definition of HSR in economic terms, namely the costs of acquisition, operating and maintenance of the specific rolling stock, estimated as "huge long-term company investments" (over 20 years); the public support of HSR undertakings, especially in Europe, with significant amounts of centralized investments; the growth in demand for HSR services, which has brought forward the idea of the "different mode of transport". Arising from the conventional railways, HSR compete successfully with the airline services over short and medium-sized distances within a continent, particularly Europe.

According to the definition of the International Union of Railways (UIC) based upon the above mentioned EC Directive 96/48, the HSR is a set of unique features, apart from the technical requirements, among which the defined above speed, namely a definite service level which is designed mainly in the field of passengers.

The distribution of lines for high-speed service could be followed in Table 1.

Table 1 Global Distribution of HSR Lines

\begin{tabular}{|c|c|c|c|}
\hline Placement & $\begin{array}{c}\text { Lines } \\
\text { constructed }(\mathrm{km})\end{array}$ & $\begin{array}{l}\text { Lines in process of } \\
\text { construction }(\mathrm{km})\end{array}$ & $\begin{array}{c}\text { Maximum } \\
\text { speed }(\mathbf{k m} / \mathrm{h})\end{array}$ \\
\hline \multicolumn{4}{|c|}{ Europe } \\
\hline Austria & 292 & 210 & 250 \\
\hline Belgium & 209 & & 300 \\
\hline Denmark & 5 & 60 & 200 \\
\hline Great Britain & 1,377 & & 300 \\
\hline Germany & 1,334 & 428 & 300 \\
\hline Italy & 923 & 125 & 300 \\
\hline Netherlands & 120 & 0 & 300 \\
\hline Poland & 85 & 322 & 200 \\
\hline Norway & 64 & 54 & 210 \\
\hline Spain & 3,100 & 1,800 & 310 \\
\hline Russia & 645 & 770 & 259 \\
\hline Finland & 610 & & 220 \\
\hline Switzerland & 80 & 57 & 250 \\
\hline $\begin{array}{c}\text { Turkey } \\
\text { (Europe-Asia) }\end{array}$ & 1,420 & 1,506 & 250 \\
\hline Total Europe & 10,264 & 5,332 & \\
\hline \multicolumn{4}{|c|}{ Asia } \\
\hline Japan & 2664 & 782 & 320 \\
\hline China & 19,000 & 18,156 & 300 \\
\hline Hong-Kong & & 26 & 200 \\
\hline South Korea & 819 & 585 & 305 \\
\hline Taiwan & 339 & 9 & 300 \\
\hline Uzbekistan & 344 & & 250 \\
\hline Total Asia & 23,166 & 19,558 & \\
\hline \multicolumn{4}{|c|}{ USA } \\
\hline & 734 & 2120 & 240 \\
\hline
\end{tabular}

Sources: (Gray, 2013) (List of high-speed railway lines, 2016)

The analysis of the data presented shows a lot of European countries, members or outside EU developing HSR. Simultaneously, 6 countries in
Asia have 2.26 times more constructed lines and 3.67 times more lines in process of construction. 
The contemporary high-speed trains in operation are able to support speed $350-400 \mathrm{~km} / \mathrm{h}$, with 560 - $580 \mathrm{~km} / \mathrm{h}$ during test runs. The possibility of developing speeds at this rate increases their competitiveness to other modes of transport, for example, the airlines, while keeping the advantages of railway passenger transport such as the comparatively lower price of travel with a large number of the carried passengers. Regular movement of high-speed trains has started in
Japan in 1964, implementing the Shinkansen project, accordingly followed in Europe first by high-speed train services in France ${ }^{1}$, then in Great Britain, Belgium ${ }^{2}$, Germany ${ }^{3}$, and Austria. Currently, most of the territory of Western Europe is united by a high-speed railway network. After the pioneer in high-speed railways Japan in $\mathrm{Asia}^{4}$, the beginning of XXI century places China as a top world leader in high-speed trains' development.
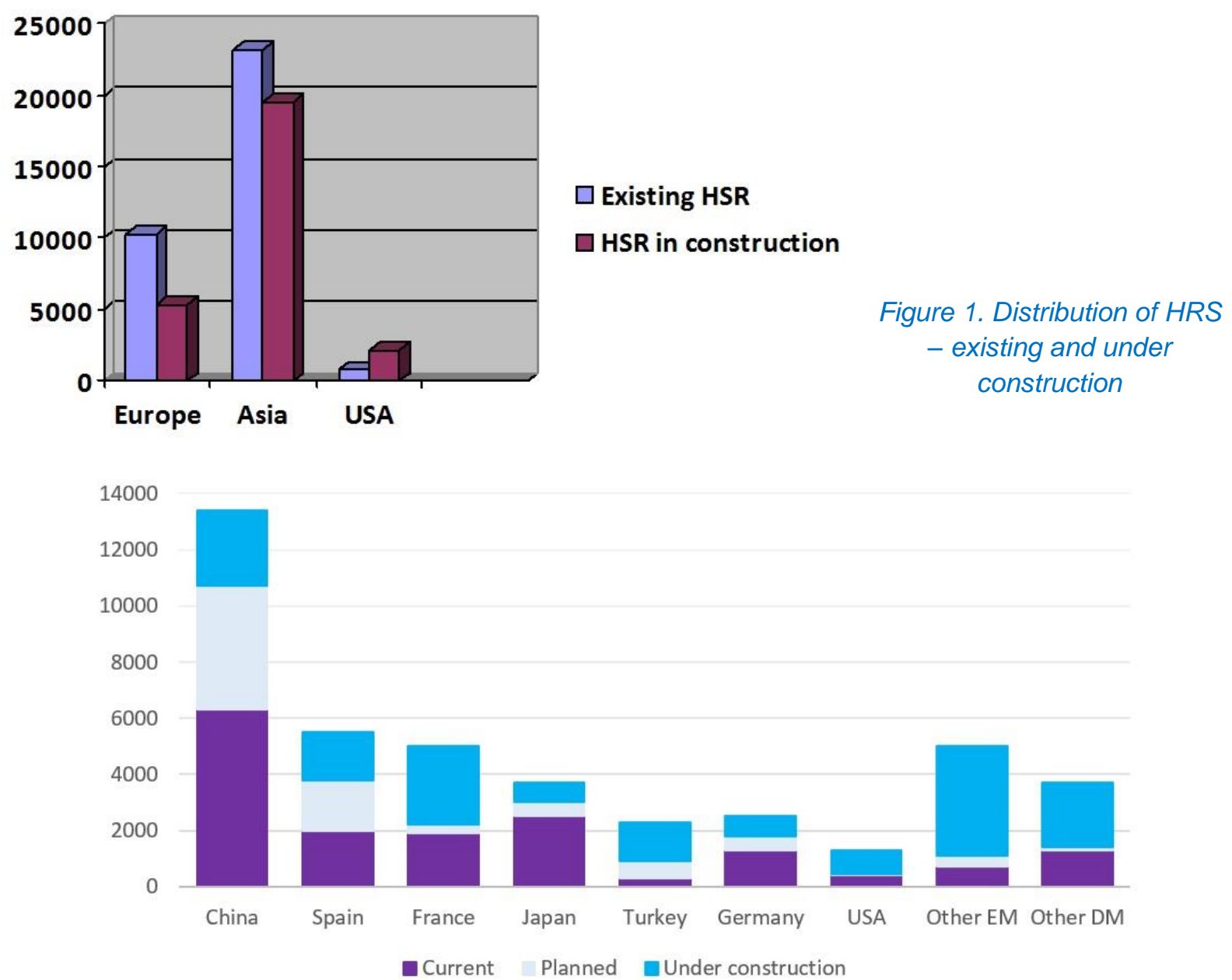

Figure 2 High-speed rail, km, selected countries

Source: Author based on (David, 2013)

Figure 2 indicates the advantage of China over all increasing speed backed-up by the intensive other countries dedicated to the development of HSR. Ever since 1993, Chinese strategy towards construction of new railway lines has been developed and implemented, involving both

1 TGV, train à grande vitesse. The Paris-Lyon highspeed rail line serves a combined population of 11.7 million people 255 miles apart (Myths/Fact, 2016).

2 Train Eurostar, connecting Great Britain and the Continent, through Eurotunnel, as well as train Thalys, connecting Brussels, Paris, Amsterdam and Cologne
3 ICE, "The Intercity-Express is the fastest and most comfortable way to travel on the DB network, reaching speeds of up to $300 \mathrm{~km} / \mathrm{h}$, and new standards of excellence" (DB, 2016)

4 Shinkansen, "New trunk line" (Johnston \& Pulling, 2007) 
passenger and freight traffic. The large-scale construction started in 1996 resulting in $19,000 \mathrm{~km}$ lines for HSR until the end of 2015 (Simeonova, 2016). The USA is almost at the end of the line; countries like India and Russia, where railway transport is well represented are not included separately.

The Indian Railways' Vision 2020 envisages a two-fold approach to developing HSR in the country. The first strategy involves using conventional technology to increase the speed on main passenger corridors from the existing 80-100 $\mathrm{km} / \mathrm{h}$ to $160-200 \mathrm{~km} / \mathrm{h}$. The second approach requires identifying viable intercity routes justifying the need to build high-speed corridors for speeds up to $350 \mathrm{~km} / \mathrm{h}$. The plans target building four corridors of 2,000 km by 2020 and planning for eight other corridors with expectations to deliver significant economic, social and environmental benefits (Shukla, Pathak, Mittal, \& Dhar, 2015).

Bearing in mind the plans to expand, the current situation in Russian HSR is represented as follows (High-speed rail in Russia, 2016):

- The Moscow - Saint Petersburg HSR, with speed of $250 \mathrm{~km} / \mathrm{h}$ (introduced at the end of 2009);

- The Moscow - Nizhny Novgorod shuttle HSR (since July 2010) Nizhny Novgorod: Highspeed traffic in Nizhny Novgorod began in July 2010.[3] Two Sapsan trains make shuttle trips between Nizhny Novgorod and Moscow, and one between Nizhny Novgorod and St. Petersburg. The latter route takes 8 hours and 30 minutes, compared to the previous 14 hours

- The HSR service between Helsinki - St. Petersburg, with $200 \mathrm{~km} / \mathrm{h}$ (started in December 2010).

The 'Strategy for the Development of Railway Transport of the Russian Federation by 2030' was approved by the Russian Government in 2008 and followed by a plan for the modernisation and development of railway infrastructure in 2011, including the construction of dedicated high-speed lines. The link Moscow - Kazan envisages $250 \mathrm{~km} / \mathrm{h}$ to be completed in 2018 . The project will be $60 \%$ financed by Russian Railways, with the remaining $40 \%$ to come from a Russian-Chinese consortium.

Only one HSR is in operation in the USA, Acela Express in the Northeast Corridor, with plans for extending these services in a number of states like California, the Midwest, New England, Florida, Texas, Pennsylvania, etc. The California HSR project was started in 2015, planning to link major cities in the state with expectations to be completed until 2029, with its first stage targeted for completion in 2017 (High-speed rail in the United States, 2016). An investigation has been carried out in USA (Feigenbaum, 2013) in order to justify the need for the development of HSR services, bringing forward several important outcomes defending the HSR idea:

- The necessity to support the sustainability of travels, based upon the expectations of increasing their number and importance on $\mathrm{HSR}^{1}$;

- The efficiency of traveling by train in terms of energy saving ${ }^{2}$; intercity passenger rail is more energy-efficient than Intercity auto trips;

- Increasing the number of train passengers does not require additional energy resources. At the same time, the increased number of road passengers affects mostly the number of vehicles on the road, additional energy costs and considerable amount of pollution substances;

- The development of HSR is further affecting positively travels for employment and leisure reasons and the access to railway travels is provided for ${ }^{3}$.

\footnotetext{
1 Americans in 2025 are projected to take 112 million trips on high-speed rail, traveling more than 25 billion passenger miles, resulting in 29 million fewer automobile trips, nearly 500,000 fewer flights, and a potential reduction of greenhouse gas emissions by 2.7 million metric tons of $\mathrm{CO}_{2}$ equivalent
}

2 Trains are 3 times as energy efficient as cars and 6 times as efficient as planes on a per-passenger-mile basis

3 The single largest employment zone in almost every metropolitan area is downtown, as are most convention 
In terms of economic development, it is considered that HSR redirects the development of travels from one mode of transport to another, meaning from air to railway transport. In terms of safety, the potential passengers consider aviation and rail as equally safe modes with a preference to the air transport. In terms of economic choice, another positive outcome is the provision of better travel conditions for public transport users with the inclusion of HSR, together with already existing options represented by the low-cost travels (by bus or plane) to aid the process of abandoning daily personalized car trips.

In 2014 the Australian Government released a study on the implementation of high-speed rail on the east coast of Australia, linking the major cities Melbourne, Canberra, Sydney and Brisbane (High Speed Rail, 2014). The initial assessment of the project on the side of Infrastructure Australia is still expected since there are recommendations to include Adelaide and Perth in it.

\section{EUROPEAN TRANSPORT POLICY, STATE OF COMPETITION AND INVESTMENTS IN HSR}

According to the Ten goals for a competitive and resource-efficient transport system: benchmarks for achieving the $60 \% \mathrm{GHG}$ emission reduction target, mentioned in the "White Paper on transport - Roadmap to a single European transport area - towards a competitive and resource-efficient transport system" (EC \& DGMT, Roadmap to a single European transport area : towards a competitive and resource efficient transport system, 2011), by 2050 the European high-speed rail network should be completed, for the majority of medium-distance passenger transport to go by rail, while the length of the existing high-speed rail network will be tripled by 2030 .

High-speed rail is controversial because highspeed trains usually depend on public subsidy, but the price of travel is often unaffordable for potential users, so losses occur and the return on investments is slow. The counter-argument, strongly supported by the European Commission is that at distances between 300 and $800 \mathrm{~km}$, fast trains between big industrial centers represent an efficient and less polluting form of public transport.

Supporting the argument for centralized investments, provided by EU and national subsidies, Europe has already added more than $6,000 \mathrm{~km}$ of high-speed tracks for high-speed travel and much more is under construction or planned. In 2015 a new line from Leipzig to Erfurt is open, while Milan-Brescia service will begin later in 2016. By 2017 four new French lines will come into service. Also, the EU plans to finance a $€ 4.5$ billion ( $\$ 5.3$ billion) in the fast-rail link between Estonia, Latvia, Lithuania, and Poland.

Figure 2 below is indicating the uneven distribution of HSR in the developed member countries of EU, for instance, France and Spain. General opinions show, that these countries may have overextended their networks, the reason being political decisions rather than economic considerations. In France, after the successful start of TGVs in 1981, traffic, revenues and profit margins have fallen considerably, because service has been deteriorated by increasing the number of stops. Spain's high-speed track is even longer than France's, and demand is less than expected.

The defendants of HSR consider the expansion of the HSL network as a new fresh breath into rail transport, thus increasing its competitiveness with other modes of transport. An example representing high speed trains accounting for approximately $40 \%$ of traffic over medium distances on certain routes ${ }^{1}$ proves that on journeys less than three hours HS trains are the most competitive form of travel, compared to air and car journey times, because of the better access to the railway carrier (EC, High speed Europe, a sustainable link between citizens, 2010).

However, competition from other forms of transport, such as low-cost airlines and longdistance coaches will keep rising due to the liberalization of passenger transport in Europe ${ }^{2}$. sport and cultural centers. This is also where rail stations are located

\section{${ }^{1}$ London-Paris, Paris-Brussels and Madrid-Seville}

2 Germany liberalized the coach market in 2013 which immediately affected high-speed routed of Deutsche 
The competitive response of high-speed rail is expressed by cutting travel prices, by SNCF in 2013 and RENFE (Spanish Railways) in 2014 to boost demand, but the effect over passengers was less than the expected.

The analysis of competition including HSR usually starts with comparing the travels with the existing conventional rail lines, since the large markets for HSR are concentrated around major cities. Passengers are divided into two groups: direct travelers between two destinations (usually provided by HSR) and travelers between smaller stations. The first group is usually estimated as sensitive towards travel time, comfort and less towards the price of travel, opposite to the members of the second group. The estimates of the market distributions for passengers show that HSR is better in serving medium and long-trip markets, while conventional railways are serving best for commuter travel and as feeders for the HSR (Hsu \& Chung, 1997).

Second, it has been reported, that on a few routes HSR has taken away certain market share from airlines, for instance, Eurostar on its main routes, Paris-Lyon and Madrid-Barcelona HS lines. Often, however, fast trains just take business away from slow trains. Between 2000 and 2011, as highspeed lines opened across the EU, rail's overall share of passenger-kilometres traveled was little changed, at $6.4 \%$ in 2011 . Cars' share had barely budged, at $72.5 \%$. Buses and coaches lost a percentage point, to $8.2 \%$, with air travel (excluding flights to outside the EU) gaining more than a point, to $8.9 \%$ (Business, 2015).

Lack of competition among rail operators is another reason why high-speed rail is failing to win passengers from other modes of transport. Despite the railway reforms as well as three railway packages of measures, with the fourth one on the way, the EU is finding it hard to establish a Pan-European market in which operators compete across borders. The competition was introduced into railway freight services; some common technical standards have been laid down to make it easier to run trains across borders, and the foundations of a single market in cross-border passenger services were laid. However, the fourth reform package, to liberalize further the market for passenger rail, has been held up by the European Parliament. Meanwhile, the national rail companies prefer cooperation to competition ${ }^{1}$.

Most active on the competition side of the busiest routes is Deutsche Bahn (DB), expressing an intention to send trains from Frankfurt through the Channel Tunnel to London, thus opposing Eurostar, in which SNCF owns a majority stake. DB is also gradually pulling out of Thalys, a venture with SNCF and its Belgian and Dutch counterparts, in preparation for competing with them on those routes.

In domestic markets, Europe's first private-sector high-speed operator in Italy, Nuovo Trasporto Viaggiatori (NTV), in which SNCF has a stake started services in 2012 and declares a market share of $20 \%$ (NTV, 2014). It has struggled to compete with the state-owned incumbent, FSI, which controls the tracks. NTV has complained to the authorities about the lack of fair competition (The Economist, 2015).

Generally, competition in railway passenger operations is strongly dependent on delayed privatization. Intention to privatize a part of FSI was expressed by the Italian government, Germany may follow about DB, but in France privatization has never been considered an option (Baron, et al., 2009).

high-speed services between the two countries (rail.cc, 2016). Lyria, owned by SNCF and its Swiss counterpart, has opened a new service between Lille and Geneva (TGV Lyria, 2016)
Bahn and a loss of $€ 50 \mathrm{~m}$ of revenues was reported in the first half of 2014. A similar liberalisation is being proposed in France, where SNCF owns a big coach operator

1 France's SNCF and Germany's Deutsche Bahn renewed a joint venture, Alleo, which manages some 


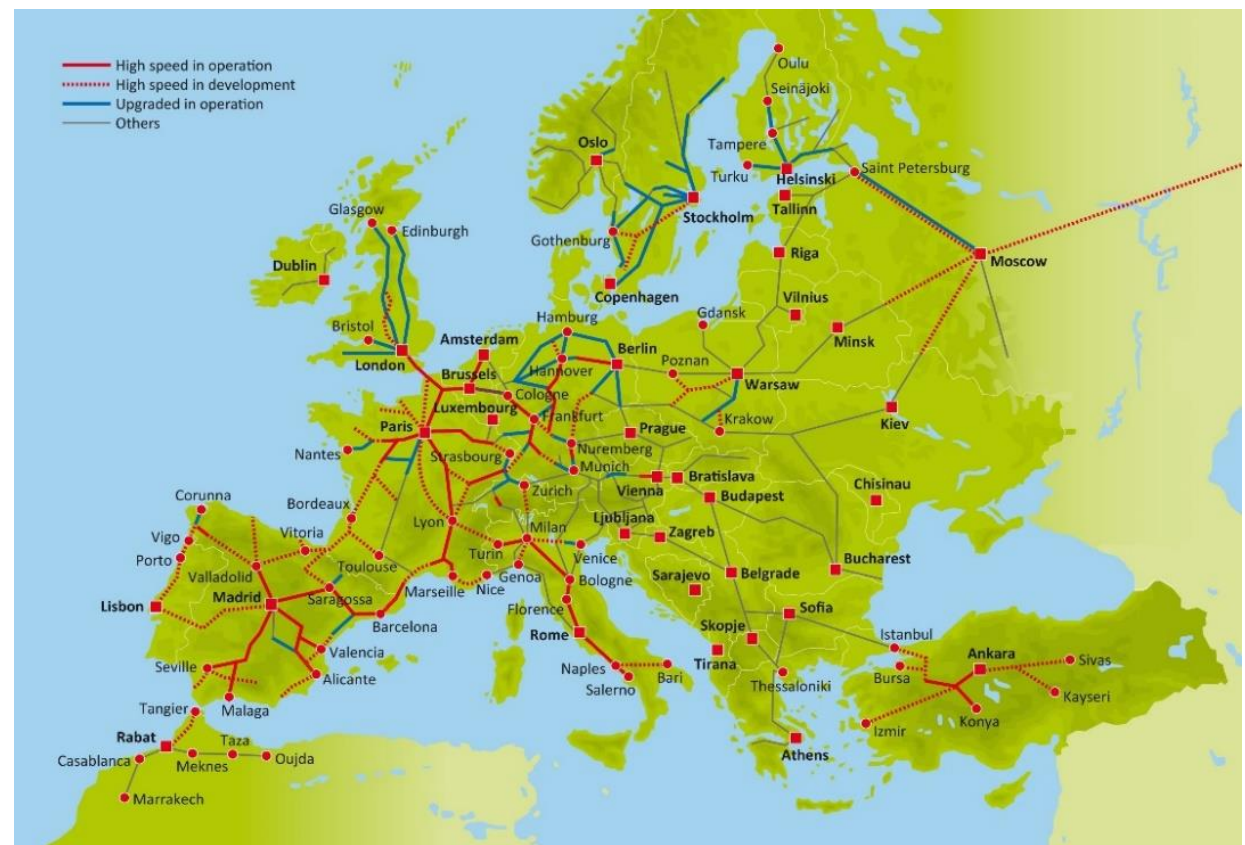

Figure 2. High-speed rail network in Europe (UIC)

Source: (UIC, 2016)

The general opinion of the ability of HSR as a means to boost long-term jobs, address regional inequalities, and provide a more sustainable global transport network less reliant on fuelconsuming planes and cars is opposed by considerations of the capital intensive HSR. Although the environmental impact of new highspeed rail routes has been widely discussed it is the economic benefits offered by these lines that need to be studied profoundly. While high-speed lines may be relevant in well-developed countries, they seem less practical in less developed regions, where the hugely expensive projects which are realized over a prolonged period of time ${ }^{1}$. The EU has been hugely in favor of developing an extensive network of high-speed rail lines that will serve some of the less developed regions, with strong connections to Europe's larger economic hubs. The US has also seen calls for a new network of high-speed lines since 2008.

The discussion paper by Ginés de Rus, University of Las Palmas, in collaboration with the OECD and the International Transport Forum, looked at the impact investment in high-speed rail could have on economies. Named 'The Economic Effects of
High-Speed Rail Investment' (Baron, et al., 2009), it says that while improved transport links from HSR might allow large companies better access to previously underserved regions, they may also hinder these regions' industrial growth. With regards to Europe's growing network of highspeed lines, de Rus adds: "The Trans-European Transport Network will give much of the EU better access to the main activity centers. However, the gap in relative accessibility between the core and peripheral areas is likely to increase as a result of the new infrastructure, which reinforces the position of core regions as transport hubs. The emphasis on high-speed rail links is also likely to favor the main nodes of the network, and is unlikely to promote the development of new activity centers in minor nodes or in locations in between nodes."

This means the benefits from HSR can vary wildly and building a network of high-speed railways across huge territories makes sense in the case of countries like China and the US, but in smaller countries, the effect is less. When a government looks to build a high-speed rail network, the scheme must offer a net social benefit greater than
1 "The impact in terms of economic exchanges, accessibility, and productivity gains are expected to be significant, and extend beyond traditional transport savings. The scale and scope of the Chinese high- speed rail programme offer a unique opportunity to measure such impacts", Gerald Ollivier, the World Bank's Senior Transport Specialist, working on China's high-speed rail network 
the next best alternative. As HSR tends not to attract private investment, the burden on the government is usually quite extreme. Air and road travel, on the other hand, is more than likely to see heavy private investment, as the returns tend to be more immediate.

De Rus concludes that the risks associated with HSR investment, including the relatively high longterm cost, almost entirely undertaken by the state mean that the particular circumstances should always be considered before decisions have been taken ${ }^{1}$. Investing in HSR can prove beneficial if conducted in the right environment. Also, there is a danger that newer technologies in transportation will boost forward in the time necessary to build a high-speed route. The question who will use the high-speed lines, when air travel provides the high speed, the self-driven cars allow for independent travels and public carriers provide Internet access and comfort to work on board remains.

\section{THE PLANS OF EXPANDING HSR}

The general review proves, that besides discussing pros and cons, among which the huge investments, the lack of certainty in the future use of HSR there are positive signs of development. The new trends envisage HSR for freight as well passenger traffic.

China plans to build more high-speed railroads in the nation's western region during the 13th (and next) Five-Year Plan (2016-2020), as well as export more high-end railway equipment products to overseas markets. China will continue to deploy more resources and manpower to further develop "smart trains", which apply intelligent technology that will allow trains 'speed control, condition determination and fault detection operations to be performed digitally (Wang, 2015).

After years of discussions and investigations, there is a wide majority support for a large investment, which includes improved public transport in Sweden. This will be the largest infrastructure project in high-speed railway between the metropolitan regions which is to be completed around 2035 (Engdahl, 2015).
The USA are committing to national planning, funding, coordination, and prioritization of rail investment. Still, intercity transportation systems require active federal engagement to guarantee the development of routes that reflect national needs and national priorities. Political consensus is required to develop national goals and focus investments on HSR (Freemark, 2014). In response to strong and continued demand for rail travel in the Northeast Corridor, Amtrak has developed a vision for Next Generation highspeed rail service on the NEC (Amtrack, 2016).

High-Speed Rail has been discussed a lot in Australia and in December 2013 the HSR Planning Authority Bill has been introduced. The Authority's major functions involve land use planning for the HSR corridor and directing the HSR's development and construction. The Authority will also consider specific measures related to environmental impacts; ensure that the HSR system provides a safe, regular, efficient and cost-effective rail transport system; and consult with interested bodies and the public on matters related to the HSR system (Coombs, 2014).

In its strategic agenda for 2020, the European Rail Research Advisory Group (ERRAC) identifies seven priority research areas for the future development of the European rail sector (ERRAC, 2007):

- intelligent mobility: implementing a passenger information system which is harmonized at European level;

- environment and energy: increasing the energy efficiency of trains, reducing environmental impacts $\left(\mathrm{CO}_{2}\right.$ emissions, noise) and researching alternative fuels, in order to minimize the dependency on fossil fuels during electricity generation;

- safety: improving safety for passengers and staff;

- homologation, testing, and safety: speeding up product approval procedures and minimizing risks through better safety management;

\footnotetext{
1 "When the investment cost associated to new highpolitical interests and subsidised rail fares, conventional speed rail lines does not pass any market test, and the visibility is reduced by industry propaganda, short-term cost-benefit analysis can help to distinguish good projects from simple 'white elephants'” (ITF, 2009)
} 
- competitiveness and technology: improving the interoperability and attractiveness of products for customers;

- economy and strategy: developing new network infrastructure-related cost management and forecast models;

- infrastructure: developing less costly maintenance methods and maintenance-free interoperable infrastructure systems.

The general opinion of the European Commission is that "......High-speed trains are a remarkable technological success, the outcome of government-funded research and development ( $R$ \& D) and the innovation of European industry, working closely with the railway companies, equipment manufacturers and civil engineers" (EC, High speed Europe, a sustainable link between citizens, 2010). For these reasons, the $\mathrm{EU}$ is laying the foundations for a north-south railway route to serve as a link between Scandinavia and Western Europe. Rail Baltica is one of the top priority projects under the TEN-T package of transport infrastructure projects within the EU. The 430-mile route will link Finland, Estonia, Latvia, Lithuania, and Poland, with an extension reaching down into Germany. The future electric railway could cost $€ 3.68 \mathrm{bn}$ to construct, but it is expected to be $85 \%$ financed by the European Union, including a $€ 124 \mathrm{~m}$ contribution granted under the TEN-T program.

Another priority project under The TEN-T agreement is an east-west high-speed axis through central Europe that would join France, Germany, Austria, and Hungary via one direct line. Sections between key cities alongside the railway's final route have been operational as far back as 2007; however, the complete route is expected to be finalized sometime after 2020, with deadlines varying for each section (Grey, 2015).

One of Great Britain's biggest infrastructure projects is designed as a long-term financial investment, uniting the northern and southern parts of the country. Planned in two phases, the HSR will reach $250 \mathrm{~km} / \mathrm{h}$, connecting 18 cities, including London, Birmingham, Manchester, and Leeds. The first leg of the track between London and Birmingham will start being built in 2017. The cost of the project is estimated at $£ 50 \mathrm{bn}$ in total.
With the early introduction of the TGV lines, France has established itself as a leader in HSR infrastructure in Europe. Since then, it has been persistent in further developing and growing its high-speed network. Another project, the South Europe Atlantic HSR, connecting Tours to Bordeaux, will be completed in 2017.

The rail line "New Silk Road" is the Eurasia rail link from the eastern China to Madrid, Spain stretched more than $13000 \mathrm{~km}$. It is longer than the TransSiberian railway and the Orient Express, also has stops in various European and Asian countries including Poland, Germany, and Russia, along with the way (Amtrack, 2016). The grand project for a high-speed freight train through the whole continent Asia, connecting Beijing to the European railway network is considered the most viable economically for China in logistic deliveries towards the European markets. This is the new era of HSR for railway freight.

China and Russia are strengthening their ties via a direct line between Moscow and Beijing that is set to become the longest HSR in the world on completion. Trains with $250 \mathrm{~km} / \mathrm{h}$ will pass a distance of about $10000 \mathrm{~km}$, traversing China, Mongolia, Kazakhstan, and Russia. Much of the distance will run in parallel with the Trans-Siberian Railway, but the HSR will reach a travel time of 33 hours.

TRASECA, the transcontinental transport corridor Europe - Caucasus - Asia was declared in 1993 at Baku, with participants Azerbaijan, Armenia, Georgia, Kirgizstan, Tajikistan, Turkmenistan, and Uzbekistan. Later, Ukraine, Mongolia, and Moldova joined, and in 2000 Bulgaria, Romania and Turkey also became a part of it. The line is crossing the ex-soviet middle Asia republics and Iran towards Turkey.

The strategic partnership between China and Turkey has been contracted and the first results are out coming. The potential required resources are big, but both countries consider them affordable, despite the consequences of the world economic crisis, by using parts of the national railway systems and constructing the necessary links between them. The project is reviving the ancient "Silk Road" as the world longest transcontinental HSR. One of the links to be constructed is the HS corridor between Ankara and Istanbul. The first stage of the track is 
completed and the second stage, from Eskisehir to Istanbul will follow to Edirne and the Bulgarian border, with the intention to be continued through Bulgaria (Vasileva, 2015). The natural and geographic background in Bulgaria allows a maximum speed of $200 \mathrm{~km} / \mathrm{h}$ at most.

The Chinese government is interested in the construction of the railway infrastructure for highspeed traffic on the route Ruse - Dimitrovgrad as well as in Ruse - Varna section, which are parts of the revived "Silk Road". The total length of the railroad needed to be reconstructed is $227 \mathrm{~km}$, with an expected construction value of 383 million Euros. The construction could be bound with concessions of the ports of Varna and Ruse (Moskovski, 2015).

On the part of EU, there is a participation in the project of Turkey in the form of a number of European companies - subcontractors of the Ankara - Istanbul line. The European Investment Bank was among the main investors in Marmaray project below the Bosphorus.

\section{WORKS CITED}

Amtrack. (2016). The Amtrak Vision for the Northeast Corridor. Retrieved from NEC Vision: https://nec.amtrak.com/high-speed-rail

Baron, I., Campos, J., Gagnepain, P., Nash, C., Ulied, A., \& Vickerman, R. (2009). Economic analysis of high speed rail. (Ginés de Rus, Ed.) Madrid, Spain: Fundacion BBVA - Rogar S.A. Retrieved from http://www.fbbva.es/TLFU/dat/inf_web_economic_analysis.pdf

Business. (2015, Jan 10). High-speed rail in Europe, Problems down the line, High-speed networks are spreading fast, but face rising competition. Retrieved from The Economist: http://www.economist.com/news/business/21638109-high-speed-networks-are-spreading-fastface-rising-competition-problems-down-line

Coombs, M. (2014, Jan 28). High Speed Rail for Australia - a fast track to the future or just the same old pipe dream? Retrieved from Parliament of Australia: http://www.aph.gov.au/About_Parliament/Parliamentary_Departments/Parliamentary_Library/ FlagPost/Blog_Filter?filterld=c64a1faf-9caa-41df-9497-fa66430f7d12

David. (2013, Mar 11). A Review of Top High-Speed Rail Countries. Retrieved from Topforeignstock.com: http://topforeignstocks.com/2013/03/11/a-review-of-top-high-speed-railcountries/

DB. (2016, Aug 02). The Intercity-Express (ICE). The fastest breed of Deutsche Bahn trains in Germany and Europe. Retrieved from DB: https://www.bahn.com/i/view/USA/en/trains/overview/ice.shtml

EC. (2010). High speed Europe, a sustainable link between citizens. Luxembourg: Publications Office of the European Union. doi:10.2768/17821

EC, \& DGMT. (2011). Roadmap to a single European transport area : towards a competitive and resource efficient transport system. doi:10.2832/30955

Engdahl, S. (2015, Oct 01). The future of high-speed rail in Sweden. Retrieved from european railway review: http://www.europeanrailwayreview.com/24901/past-issues/issue-5-2015/the-future-ofhigh-speed-rail-in-sweden/

ERRAC. (2007, May). Strategic rail research and innovation agenda 2020. Retrieved from European Rail Research Advisory Council: http://demo.oxalis.be/errac/errac_website/wpcontent/uploads/2013/06/SRRA-2007.pdf

European Commission. (2004). The Trans-European High-Speed Rail System - Guide for the Application of the high-speed TSIs of Council Directive 96/48/EC, Annex 1. Luxembourg: Office for Official Publications of the European Communities. Retrieved from http://ec.europa.eu/transport/modes/rail/interoperability/doc/2003_high_speed_rail_tsi_guide_ en.pdf 
Feigenbaum, B. (2013, May). High-Speed Rail in Europe and Asia: Lessons for the United States. Retrieved from Reason: http://reason.org/files/high_speed_rail_lessons.pdf

Freemark, Y. (2014, Aug 13). Why Can't the United States Build a High-Speed Rail System? Retrieved from citylab: http://www.citylab.com/politics/2014/08/why-cant-the-united-states-build-a-highspeed-rail-system/375980/

Gray, J. (2013, July 03). The need for high-speed rail). Retrieved from World Finance: http://www.worldfinance.com/special-reports/the-need-for-high-speed-rail

Grey, E. (2015, July 09). Connecting Eurasia: mapping the myriad of high-speed rail routes. Retrieved from Railway-technology.com: http://www.railway-technology.com/features/featureconnectingeurasia-mapping-the-myriad-of-high-speed-rail-routes-4593227/

High Speed Rail. (2014, Dec 08). Retrieved from Australian Government - The Department of Infrastructure and Regional Development: https://infrastructure.gov.au/rail/trains/high_speed/

High-speed rail in Russia. (2016, June 23). Retrieved from Wikipedia: https://en.wikipedia.org/wiki/Highspeed_rail_in_Russia

High-speed rail in the United States. (2016, Aug 27). Retrieved from Wikipedia: https://en.wikipedia.org/wiki/High-speed_rail_in_the_United_States

Hsu, C.-I., \& Chung, W.-M. (1997, May). A model for market share distribution between high-speed and conventional rail services in a transportation corridor. The Annals of Regional Science, 31(2), 121-153. doi:10.1007/s001680050042

ITF. (2009). Competitive Interaction between Airports, Airlines and High-Speed Rail, Round table 145. ITF.

Johnston, H., \& Pulling, N. (2007, Sep 03). Japanese Bullet Trains - 40 Years at the Forefront. Retrieved from railway-technology.com: http://www.railway-technology.com/features/feature1216/

List of high-speed railway lines. (2016, Aug 21). Retrieved from Wikipedia: https://en.wikipedia.org/wiki/List_of_high-speed_railway_lines

Moskovski, I. (2015, Nov 25). Resheno: Kupuvame visokoskorostni vlakove. Retrieved from Novinite.bg: http://novinite.bg/articles/102809/Resheno-Kupuvame-visokoskorostni-vlakove

Myths/Fact. (2016, Apr 20). Retrieved from High-speed rail works: http://highspeedrailworks.org/overview-2/myths-facts/

NTV. (2014). Bilancio dell'esercizio chiuso il 31/12/2013. Retrieved from Nuovo Transporto Viaggiatori: http://www.ntvspa.it/ /media/NtvSpa\%20lmage/ntvupload/utils/12012015_043940NTV\%20Bil ancio\%202013\%20ITA.pdf

rail.cc. (2016). TGV Alleo (Alleo) - Drance. Retrieved from rail.cc: https://en.rail.cc/train-type-country/tgvalleo/sncf-alleo/172

Shukla, P., Pathak, M., Mittal, S., \& Dhar, S. (2015). Scenarios and Roadmap for Intercity Transport in India: The Role of High Speed Rail. New Delhi, India: UNEP. Retrieved from http://www.unep.org/transport/lowcarbon/PDFs/Role_of_High_Speed_Rail_Final.pdf

Simeonova, L. (2016, Aug 17). Kitai zalaga na visoko-skorostnite zheleznitsi. Retrieved from Kitai dnes: http://www.kitajdnes.com/index.php?option=com_content\&view=article\&id=391:kitai-zalagana-visoko-skorostnite-zheleznitzi\&catid=195:savremenen-kitai\&ltemid=397\&lang=bg

TGV Lyria. (2016). Edavez-vous en Suisse en seulement 3 heures de train. Retrieved from TGV Lyria: http://www.tgv-lyria.com/fr 
The Economist. (2015, Jan 10). High-speed rail in Europe, Problems down the line, High-speed networks are spreading fast, but face rising competition. Retrieved from The Economist: http://www.economist.com/news/business/21638109-high-speed-networks-are-spreading-fastface-rising-competition-problems-down-line

UIC. (2016). High Speed. UIC. Retrieved from http://www.uic.org/highspeed

Vasileva, E. (2015, Jan 30). Visokoskorosten vlak shte svrzhe Istanbul s granitsata s Bulgariya. Retrieved from High speed train connecting Istanbul to the Bulgarian border, Dnes.bg, : http://www.dnes.bg/balkani/2015/01/30/visokoskorosten-vlak-shte-svyrje-istanbul-s-granicatas-bylgariia.252934

Wang, B. (2015, Oct 29). China plans to triple high speed rail network to over 31000 miles and boost speed from $240 \mathrm{mph}$ to $310 \mathrm{mph}$ by 2020 . Retrieved from netBIG Future: http://www.nextbigfuture.com/2015/10/china-plans-to-triple-high-speed-rail.html

Grey, Eva, Railway-technology.com, Connecting Eurasia: mapping the myriad of high-speed rail routes, http://www.railway-technology.com/features/featureconnecting-eurasia-mapping-the-myriadof-high-speed-rail-routes-4593227/

Amtrack. The Northeast corridor, NEC Vision http://spendmatters.com/2015/01/08/chinas-freightsystem-future-is-a-high-speed-rail-possible

Vasileva, E., High speed train connecting Istanbul to the Bulgarian border, Dnes.bg, http://www.dnes.bg/balkani/2015/01/30/visokoskorosten-vlak-shte-svyrje-istanbul-s-granicatas-bylgariia. 252934

Simeonova, L., http://www.kitajdnes.com/index.php?option=com_content\&view=article\&id=391:kitaizalaga-na-visoko-skorostnite-zheleznitzi\&catid=195\&ltemid=397\&lang=bg

P. R. Shukla, IIM, A. M. Pathak, CUE and Faculty of Planning, CEPT University, Shivika Mittal, NIES, Tsukuba, Japan, Subash Dhar, UNEP DTU Partnership, Copenhagen, Denmark, Scenarios and Roadmap for Intercity Transport in India: The Role of High Speed Rail, September 2015, http://www.unep.org/transport/lowcarbon/PDFs/Role_of_High_Speed_Rail_Final.pdf

High-speed rail in Russia, https://en.wikipedia.org/wiki/High-speed_rail_in_Russia

High-speed rail in USA, https://en.wikipedia.org/wiki/High-speed_rail_in_the_United_States

Parliamentary Library of Australia, http://www.aph.gov.au/Parliamentary_Library/FlagPost/2014/January/high-speed-rail

European Rail Research Advisory Council, 'Strategic rail research agenda 2020', May 2007 (www.errac.org)

High speed Europe, A sustainable link between citizens, DG for Mobility and Transport, Luxembourg, Publication Office of EU, 2010, ISBN 978-92-79-13620-7, http://ec.europa.eu/transport/themes/infrastructure/studies/doc/2010_high_speed_rail_en.pdf, p. 18

Feigenbaum, Baruch, High-Speed Rail in Europe and Asia: Lessons for the United States, http://reason.org/files/high_speed_rail_lessons.pdf

Department of Infrastructure and Regional Development, https://infrastructure.gov.au/rail/trains/high_speed/

High speed Europe, Luxembourg: Publications Office of the European Union, 2010 ISBN 978-92-7913620-7 doi: 10.2768/17821 (C) European Union, 2010, http://ec.europa.eu/transport/themes/infrastructure/studies/doc/2010_high_speed_rail_en.pdf 
Chaug-Ing Hsu, Wen-Ming Chung, A model for market share distribution between high-speed and conventional rail services in a transportation corridor, The Annals of Regional Science, May 1997, Volume $31, \quad$ Issue $2, \quad$ pp 121-153, http://link.springer.com/article/10.1007\%2Fs001680050042

The Economist, High-speed rail in Europe, Problems down the line, High-speed networks are spreading fast, but face rising competition, Jan 10th 2015, http://www.economist.com/news/business/21638109-high-speed-networks-are-spreading-fastface-rising-competition-problems-down-line

Ginés de Rus (ed.), Baron, Ignacio, Javier Campos, etc., Economic Analysis of High Speed Rail in Europe, http://www.fbbva.es/TLFU/dat/inf_web_economic_analysis.pdf

Wang, Brian, China plans to triple high speed rail network to over 31000 miles and boost speed from $240 \mathrm{mph}$ to $310 \mathrm{mph}$ by 2020, Coverage of Disruptive Science and Technology, October 29, 2015, http://nextbigfuture.com/2015/10/china-plans-to-triple-high-speed-rail.html

Stefan Engdahl, Director of Market and Planning at the Swedish Transport Administration (Trafikverket), The future of high-speed rail in Sweden. October 1, 2015, European railway review, http://www.europeanrailwayreview.com/24901/past-issues/issue-5-2015/the-future-of-highspeed-rail-in-sweden

Freemark, Yonah, Why Can't the United States Build a High-Speed Rail System? August 13, 2014, CityLab Series, The Future of Transportation, http://www.citylab.com/politics/2014/08/why-cantthe-united-states-build-a-high-speed-rail-system/375980

Received for publication: 30.03.2017

Revision received: $\quad 20.04 .2017$

Accepted for publication: 01.05.2017

\section{How to cite this article?}

Style - APA Sixth Edition:

Kirova, A. (2017, July 15). The HSR as an innovative and ecological mode of transport. (Z. Čekerevac, Ed.) MEST Journal, 5(2), 65-77. doi:10.12709/mest.05.05.02.07

Style - Chicago Sixteenth Edition:

Kirova, Antoaneta. "The HSR as an innovative and ecological mode of transport." Edited by Zoran Čekerevac. MEST Journal (MESTE) 5, no. 2 (July 2017): 65-77.

Style - GOST Name Sort:

Kirova Antoaneta The HSR as an innovative and ecological mode of transport [Journal] // MEST Journal / ed. Čekerevac Zoran. - Toronto - Belgrade : MESTE, July 15, 2017. - 2 : Vol. 5. - pp. 65-77.

Style - Harvard Anglia:

Kirova, A., 2017. The HSR as an innovative and ecological mode of transport. MEST Journal, 15 July, 5(2), pp. 65-77.

Style - ISO 690 Numerical Reference:

The HSR as an innovative and ecological mode of transport. Kirova, Antoaneta. [ed.] Zoran Čekerevac. 2, Toronto - Belgrade : MESTE, July 15, 2017, MEST Journal, Vol. 5, pp. 65-77. 